\title{
Evaluation of Selected Heavy Metals and Macronutrients Status of 10 Medicinal Plants from Nigeria
}

\author{
Ibironke A. Ajayi ${ }^{1}$, Rotimi A. Oderinde ${ }^{1}$, Adewale Adewuyi ${ }^{1}$ Joseph I. Uponi ${ }^{2}$, \\ ${ }^{1}$ Industrial Unit, Chemistry Department, Faculty of Science, University of Ibadan, Ibadan, Nigeria \\ ${ }^{2}$ International Institute of Tropical Agriculture, PMB 5320, Ibadan, Oyo state, Nigeria
}

\begin{abstract}
Ten important herbal plants from the South-west of Nigeria were analyzed for their heavy metal (K, $\mathrm{Na}, \mathrm{Ca}, \mathrm{Mn}, \mathrm{Mg}, \mathrm{Cu}, \mathrm{Fe}, \mathrm{Zn}, \mathrm{Pb}$ and $\mathrm{P})$ and macro-nutrient status using an atomic absorption spectrophotometer. The most prevalent heavy metals were $K(162-524 \mathrm{mg} / \mathrm{mL})$ and Ca $(102-472 \mathrm{mg} / \mathrm{mL})$ followed by $\mathrm{Mg}(48.10-136.00 \mathrm{mg} / \mathrm{mL})$ and $\mathrm{Na}(3.51-10.10 \mathrm{mg} / \mathrm{L})$. The highest level of $\mathrm{K}(524.00 \pm$ $5.70 \mathrm{mg} / \mathrm{mL})$ and $\mathrm{Ca}(472.00 \pm 1.44 \mathrm{mg} / \mathrm{mL})$ were found in Senna alata and Senna podocarpa, respectively. Out of all the plants, Dissotia rotundifolia had the highest concentrations of $\mathrm{Mg}(136.00 \pm 0.28 \mathrm{mg} / \mathrm{mL})$ and $\mathrm{Na}$ $(10.10 \pm 0.03 \mathrm{mg} / \mathrm{mL})$. The results showed that the level of $\mathrm{Cu}(0.65-1.48 \mathrm{mg} / \mathrm{mL})$ and $\mathrm{Zn}(2.40-6.77 \mathrm{mg} / \mathrm{mL})$ found in the herbal plants were much lower than the reported range of the elements in agricultural products.

Keywords: medicinal plants, digestion, macronutrient status, agricultural products
\end{abstract}

\section{Introduction}

The role of trace elements in human nutrition and disease cannot be over-emphasized. Even though the mineral elements form a small proportion of total composition of most plant materials and of total body weight and they do not contribute to energy value of food, they are of great physiological importance particularly in the body metabolism (Schwart, 1995). Their importance ranged from role as biological essential components to imbalance created when excess of one interferes with the functions of another. Mineral elements function as mineral electrolyte and ions performing osmotic and regulatory functions in the body fluid dynamics. Various minerals are also co-enzymes in certain biochemical reactions in the body (Mensah et al., 2008). Records from ancient Egypt, Assyria, China and India show that the use of plants for medicinal purposes extends back to earliest recorded history (Trease, 1989). Today, it is recognized that these elements play an important role in nutrition. Their functions are varied and may depend on their chemical forms or their location in the body tissues or blood fluids. Many elements form important part of enzymes to increase the rate of chemical reactions in the cells. These enzymes can be used over and over again because the elements can be effective even when present in only very low concentration in the cells of the body. All plants contain varying amount of mineral element. The extent to which plants take up metals depends on the binding of trace analytes to soil constituents; other sources may include pesticides and fertilizers (Ansari et al., 2009). Majority of the Africans today depend either totally or partially on traditional medicine called ethno medicine for healing. Today in Nigeria, there is an increase in the acceptance and utilization of traditional medicine partly because of scientific support for some of their medicinal uses (Odetola and Akojeun, 2000). Many medicinal plants are cheaper and more accessible to most people in the developing countries than orthodox medicine, and there is lower incidence of adverse effects after use (Sofowora, 1993). Trace minerals have both curative and preventive role in combating diseases but according to Schumacher (1991), they can be dangerous and toxic when in excess. It is therefore important that the levels of some of these mineral elements in herbal plants be established. The need to ensure the quality control of plant products using modern techniques and applying suitable standards have been emphasized by the World Health Organization (1992). This paper reports on the evaluation of mineral element composition of ten selected medicinal plants from Nigeria. Ajasa et al. (2004) have reported on the heavy trace metal and macronutrient status of some herbal plants of Nigeria and there are many literature reports on the determination of metal content of herbal, medicinal and aromatic plants from other parts of the world (Majid et al. 1995; Vartika et al. 2001) but no literature data are available on the mineral element composition of these particular medicinal plants that are evaluated.

\section{Materials And Methods}

Material

Ten different medicinal plants were used in this work (Table 1): Sida acuta, Mormodica charantia, Boerhaavia diffusa, Gossypium hirsutum and Occimium gratissimum were collected from the Botanical Garden of the University of Ibadan while Phyllantus reticulata, Paullina pinnata, Senna podocarpa, Senna alata and Dissotis rotundifolia were collected from the Botany and Microbiology Department also within University of 
Ibadan. The plants were identified by the Herbarium Unit of Department of Botany, University of Ibadan, Ibadan. The samples were air dried and then pulverized.

\section{Reagents}

Analytical reagent grade concentrated acids (HCIO4 and HNO3) were used. Ultra-pure water was used during the course of the experiment. Stock standard solutions containing $1000 \mathrm{ppm} \mathrm{Na}, \mathrm{K}, \mathrm{Mg}, \mathrm{Ca}, \mathrm{Fe}, \mathrm{Pb}, \mathrm{Zn}$, $\mathrm{Mn}, \mathrm{Cu}$ and $\mathrm{P}$ were used. An appropriate dilution of the stock solutions gave the calibrations standards of each element. All chemicals were purchased from Merck Chemicals, Nottingham, UK.

\section{Atomic absorption spectrophotometer}

An atomic absorption spectrophotometer (AAS; Analysengerate GmbH model 200A; Buck Scientific, Germany) was used for metal determination with Cathodeon (England) hollow cathode lamps for K, Mg, Ca, Zn and $\mathrm{Mn}$, Buck Scientific hollow cathode lamps for $\mathrm{Cu}, \mathrm{Na}$ and $\mathrm{Pb}$, and Fischer Scientific hollow cathode lamps for $\mathrm{Fe}$, used as radiation sources. The elements were measured under the optimum operating conditions with an air-acetylene flame. Phosphorus levels of the plants samples were determined by a colorimeter (Technicon AAII Autoanalyzer) at $630 \mathrm{~nm}$. An ultra-pure water filter (Elgastat UHQ machine, Veolia, UK) was used to generate the ultra-pure water for dilution. Distilled water was used to generate ultra pure water.

\section{Sample treatment}

Samples were digested by the wet ashing method using concentrated nitric and perchloric acids (1: 1 , $\mathrm{v} / \mathrm{v}$ ) following the methods of Ajayi et al. (2004) and Akwaowo et al. (2000). The digests were filtered into a $100-\mathrm{ml}$ standard flask and made up with ultrapure water. $\mathrm{Mg}, \mathrm{Ca}, \mathrm{Fe}, \mathrm{Pb}, \mathrm{Zn}, \mathrm{Mn}$ and $\mathrm{Cu}$ were determined by absorption and $\mathrm{Na}$ and $\mathrm{K}$ by emission using a Buck Scientific model 200A AAS.

\section{Statistical analysis}

The samples $(0.50 \mathrm{~g})$ were separately digested and subjected to analysis as described above. The analysis was carried out in triplicate per sample. The results obtained were statistically analyzed by one way analysis of variance (ANOVA). Means were compared by the Duncan's multiple range test (Duncan 1955); significant differences between any two means were determined at the $5 \%$ level.

\section{Results And Discussion}

The mineral concentrations of the medicinal plants tested are shown in Table 2. The mineral elements which were determined by AAS numbered 10: $\mathrm{Na}, \mathrm{K}, \mathrm{Ca}, \mathrm{Mg}, \mathrm{Zn}, \mathrm{Cu}, \mathrm{Fe}, \mathrm{Pb}, \mathrm{P}$ and $\mathrm{Mn}$. There are many factors which can influence the concentration of various elements in plants. These include the nature of the element, its content and form in the soil, soil type and $\mathrm{pH}$, the crop variety, proximity to external sources of pollution and many other factors (Femenia et al., 1995; Adeleke and Abiodun, 2010). All the plants appeared to be an important source of minerals as the result from the study showed that the metals were accumulated to some extent by the medicinal plants. Elemental studies of the plants showed that they contained a large amount of nutrients and were rich in $\mathrm{K}, \mathrm{Ca}$ and $\mathrm{Mg}$. The presence of important mineral elements inside these plants shows that they could be nutritious plants (Jonathan et al., 2011). Significant variations occurred in the mineral concentration among the samples analyzed.

The Na concentration levels ranged from $3.51 \pm 0.03 \mathrm{mg} / \mathrm{L}$ to $10.14 \pm 0.03 \mathrm{mg} / \mathrm{L} ; S$. acuta had the lowest while $D$. rotundifolia had the highest; most samples had a Na concentration between $4.64 \pm 0.06$ and $6.89 \pm 0.03 \mathrm{mg} / \mathrm{L}$. The Na concentration in S. alata, O. gratissimum and B. diffusa were comparable. The values for M. charantia, P. pinnata and G. hirsutum were also comparable and similarly those for S. podocarpa and $P$. reticulate. The Na contents in these medicinal plants were higher than those reported in the literature by Onyeike and Acheru (2002) for castor, coconut, dikanut, groundnut, melon, oil bean and palm kernel seeds (Table 3) used in the preparation of Nigerian diets. Sodium is known to play a crucial role in conduction of nerve impulse (Oderinde et al., 2008). The medicinal plants had a K concentration in the range of $162.00 \pm 2.82$ to $524.00 \pm 5.70 \mathrm{mg} / \mathrm{L}$. The K concentration was comparable in P. pinnata, P. reticulata and S. podocarpa. S. alata had the highest while $S$. acuta had the lowest values. Potassium concentration of the plants is higher than those reported for fresh fish (Oreochromis niloticus, Clarias lazera and Mormyrus rume) samples (Otitologbon et al., 1997). $\mathrm{K}$ is the most mportant intracellular element that is required for various physiological functions (Olaniyi et al., 1993). Potassium is also good for nerves and muscle functions (Komolafe et al., 2006). $\mathrm{Mg}$ concentration was highest in D. rotundifolia and lowest in P. pinnata; the concentration ranged from 47.30 \pm 0.28 to $136.14 \pm 0.28 \mathrm{mg} / \mathrm{L}$. The concentration was comparable for P. reticulata, O. gratissimum, G. hirsutum, S. podocarpa and S. alata.

The result of the elemental study of the medicinal plants showed that the Ca concentration ranged from $102.00 \pm 0.00$ to $472.00 \pm 1.44 \mathrm{mg} / \mathrm{L}$, most samples being in the range of $203.85 \pm 2.81$ to $278.54 \pm 1.41 \mathrm{mg} / \mathrm{L}$. 
G. hirsutum had the highest Ca concentration while S. acuta had the lowest. The Ca content of these plants was higher than those obtained for watermelon (Citrullus vulgaris) and pumpkin (Cucurbita pepo) seed kernel and paprika (Capsicum annuum) seed flour (El-Adawy and Taha, 2001) (Table 3). The Pb concentration levels ranged from $0.03 \pm 0.00$ to $0.13 \pm 0.01 \mathrm{mg} / \mathrm{L}$; a large number of the plant samples that were studied in the present work had values between $0.03 \pm 0.00$ and $0.06 \pm 0.00 \mathrm{mg} / \mathrm{L}$. S. acuta had the highest while P. reticulata and $M$. charantia had the lowest. The concentration of $\mathrm{Pb}$ was also the same for D. rotundifolia, G. hirsutum, $S$. podocarpa and O. gratissimum. This is comparable to the result reported by Ajasa et al. (2004) in which the concentration of $\mathrm{Pb}$ was comparable in Anacardium occidentalis and Azadirachta indica, Butyrospermum paradoxum, Mangifera indica, Zingiber officinales and Hyptis suaveolens and similarly between Ocimum canum, Morinda lucida, Solanum erianthum and Solanum torvum in a range of 0.31-0.35 mg/L. The level of Pb accumulation in the plant samples is well below $10 \mathrm{mg} / \mathrm{mL}$, which is the permissible limit for medicinal plants (Aliyu et al., 2008). The $\mathrm{Zn}$ concentration varied from $2.40 \pm 0.11$ to $6.77 \pm 0.08 \mathrm{mg} / \mathrm{L}$; four of the samples had $<3.00 \mathrm{mg} / \mathrm{L}$. S. alata had the lowest $\mathrm{Zn}$ concentration and B. diffusa the highest. $\mathrm{Zn}$ is required to prevent growth and mental retardation in humans (Fagbemi, 2007). The concentration of $\mathrm{Zn}$ was comparable in $S$. alata, $S$. podocarpa, $P$. pinnata and $O$. gratissimum with a range of $2.40 \pm 0.08$ to $2.87 \pm 0.11 \mathrm{mg} / \mathrm{L}$ while $P$. pinnata and $O$. gratissimum had the same value, $2.80 \pm 0.08 \mathrm{mg} / \mathrm{L}$.

$\mathrm{Cu}$ is involved in many physiological and biochemical reactions in humans. It is ubiquitous and is an essential trace element for animals and plants (Donde and Virkar 1996). Its concentration in the medicinal plants studied ranged from $0.65 \pm 0.01$ to $1.48 \pm 0.01 \mathrm{mg} / \mathrm{L}$. $\mathrm{Cu}$ and $\mathrm{Zn}$ are usually considered as micronutrients. According to Allaway (1968) and Ajasa et al. (2004) the range of elements in agricultural products should be between $4-15 \mathrm{mg} / \mathrm{L}$ for $\mathrm{Cu}$ and $15-20 \mathrm{mg} / \mathrm{L}$ for $\mathrm{Zn}$. The results obtained from the herbal plants studied, when compared with these values, showed that the plants accumulate these metals in ranges that fall within limits proposed by these authors. The P concentration in the medicinal plants analyzed varied from $26.80 \pm 0.42$ to $59.90 \pm 2.74 \mathrm{mg} / \mathrm{L} ;$ S. acuta had the lowest while P. reticulata had the highest values. Phosphorus is needed for bone growth, kidney function and cell growth; it also plays a role in maintaining the body's acid-alkaline balance (Nzikou et al., 2006). The level of P concentration was comparable in four of the samples: $M$. charanta, $S$. podocarpa, G. hirsutum and O. gratissimum in a range of $31.40 \pm 3.13$ to $36.00 \pm 0.00 \mathrm{mg} / \mathrm{L}$. The $\mathrm{Fe}$ concentration ranged from $3.96 \pm 0.01$ to $20.20 \pm 0.14 \mathrm{mg} / \mathrm{L}$, with most of the values lying between $4.33 \pm 0.03$ to $7.65 \pm 0.01 \mathrm{mg} / \mathrm{L}$. P. reticulata had the lowest Fe concentration while D. rotundifolia had the highest. The Fe content $6.98 \pm 0.01 \mathrm{mg} / \mathrm{mL}$ of $S$. acuta is the same as $6.98 \pm 0.43 \mathrm{mg} / 100 \mathrm{~g}$ that was obtained for soybean products (Garcia et al., 1998). The relatively high concentration of Fe in the medicinal plants $(3.96 \pm 0.01$ for $P$. reticulate to $20.20 \pm 0.14 \mathrm{mg} / \mathrm{mL}$ for $D$. rotundifolia) is quite encouraging because of its requirements for blood formation (Oladele and Aina, 2007); it may perhaps provide the opportunity of using these plants as a food tonic for convalescing patient. Mn concentration ranged from $0.27 \pm 0.00$ to $2.10 \pm 0.00 \mathrm{mg} / \mathrm{L}$; most samples had contents from $0.32 \pm 0.00$ to $0.71 \pm 0.00 \mathrm{mg} / \mathrm{L}$. S. podocarpa had the lowest Mn concentration while $D$. rotundifolia had the highest. Vegetables are known to supply the needed vitamins and also $\mathrm{Fe}, \mathrm{Ca}, \mathrm{Mg}, \mathrm{Zn}$ and other minerals which are important for human health and they are the most affordable source of minerals and vitamins for African families (Schutlink et al., 1987; Rossel, 1991; Ajayi and Aghanu, 2011). Though much is known about the functional role of a number of elements, the best foreseeable benefit for human health, by mineral nutrition, is in obtaining the correct amount of supplementation in the right form at the right time. The contents found for the mineral elements studied may suggest that their use in moderate quantities would provide the range of amounts of $\mathrm{Cu}, \mathrm{Fe}$ and $\mathrm{Zn}$ necessary for a healthy diet. $\mathrm{P}$ and $\mathrm{Zn}$ play crucial roles in actively metabolizing cells, particularly in relation to energy metabolism and photo-synthesizing of leaves; they also play key roles in energy cycle. $\mathrm{Mg}$ and $\mathrm{Fe}$ are components of chlorophyll.

$\mathrm{Ca}$ is an indispensable component of the structure of the body. The bones and teeth owe their hardness and strength to the presence of these minerals (Uddoh, 1998). Ca is aided in its structural role by its interactions with $\mathrm{P}$ and $\mathrm{Mg}$. It forms about $2 \%$ of the body although there are individual variations. The adult body contains an average of $1200 \mathrm{~g}$, over $90 \%$ of which is present in the bones and teeth. The remaining $\mathrm{Ca}$ is present in all tissue cells and extra cellular fluids or in the blood plasma in a state of constant exchange with the skeletal $\mathrm{Ca}$. $\mathrm{Mg}$ works with $\mathrm{Ca}$ to maintain healthy bones (Ajayi et al., 2007). Calcium, potassium and magnesium are required for repair of worn out cells, strong bones and teeth in humans, building of red blood cells and for body mechanisms (Aliyu et al., 2008). The concentrations of $\mathrm{K}, \mathrm{Mg}$ and $\mathrm{Ca}$ in the medicinal plants make them sources of these mineral elements and, if included in a diet, can supply the body with them.

\section{Acknowledgements}

The authors wish to acknowledge the Department of Chemistry, University of Ibadan and International Institute for Tropical Agriculture both in Ibadan, Nigeria for their facilities. 


\section{References}

[1]. Adeleke RO, Abiodun OA (2010) Nutritional composition of breadfruit seed (Artocarpus camansi). African Journal of Agricultural Research 5, 1273- 1276

[2]. Ajasa AMO, Bell MO, Ibrahim AO, Ogunwande IA, Olawore NO (2004) Heavy trace metals and micronutrients status in herbal plants of Nigeria. Food Chemistry 85, 67-71

[3]. Ajayi IA, Dawodu FA, Adebowale KO, Oderinde RA (2004) A study of the oil content of Nigeria grown Monodora myristica seeds for its nutritional and industrial applications. Pakistan Journal Industrial Research 47, 60-65

[4]. Ajayi IA, Oderinde RA, Ogunkoya BO, Egunyomi A, Taiwo VO (2007) Chemical analysis and preliminary toxicological evaluation of Garcinia mangostana seeds and seed oil. Food Chemistry 101, 99-1004

[5]. Ajayi IA, Oderinde RA, Taiwo VO, Agbedana EO (2008) Short-term toxicological evaluation of Terminalia catappa, Pentaclethra macrophylla and Calophyllum inophyllum seed oils in rats. Food Chemistry 106, 458-465

[6]. Ajayi IA, Aghanu VN (2011) Chemical characterization of Monodora tenuifolia seeds from Nigeria. Seed Science and Biotechnology $5,59-62$

[7]. Akwaowo EU, Ndon BA, Etuk EU (2000) Minerals and antinutrients in fluted pumpkin (Telfairia occidentalis Hook F.). Food Chemistry $70,235-240$

[8]. Allaway WH (1968) Agronomic controls over environmental cycling of trace elements. Advances in Agronomy 20, 235-274

[9]. Aliyu AB, Musa AM, Oshanimi JA, Ibrahim HA, Oyewale AO (2008) Phytochemical analyses and mineral elements composition of some medicinal plants of Northern Nigeria. Nigerian Journal of Pharmaceutical Sciences 7, 119-125

[10]. Ansari R, Kazi TG, Jamali MK, Arain MB, Wagan MD, Jaibani N, Afridi HI, Shah AQ (2009) Variation in accumulation of heavy metals in different verities of sunflower seed oil with the aid of multivariate technique. Food Chemistry 115, 318-323

[11]. Dalziel JM (1937) The Useful Plants of West Tropical Africa, Royal Botanical Gardens, Singapore, pp 27-78

[12]. Donde UM, Virkar K (1976) Effect of oral contraceptives and injectables on serum copper levels. Industrial Journal of Medical Research 64, 768-901

[13]. Duncan DB (1955) Multiple range and multiple F tests. Biometrics 11, 1-42

[14]. Duschenkov V, Kumar PBAN, Motto H, Raskin I (1995) Rhizofiltration: The use of plants to remove heavy metals from aqueous streams. Environmental Science and Technology 29, 1239-1245

[15]. El-Adawy TA, Taha KM (2001) Characteristics and composition of different seed oils and flours. Food Chemistry 74, 47-54

[16]. Fagbemi TN (2007) Effects of processing on the nutritional composition of fluted pumpkin (Telfaria occidentalis) seed flour. Nigeria Institute of Food Science and Technology 25, 1-22

[17]. Femenia A, Rossello C, Mulet A, Canellas J (1995) Chemical composition of bitter and sweet apricot kernels. Journal of Agriculture and Food Chemistry 43, 356-361

[18]. Garcia MC, Marina ML, Laborda F, Torre M (1998) Chemical characterization of commercial soybean products. Food Chemistry 62, $325-331$

[19]. Gbolacade JA, Ajayi I, Omitade Y (2011) Nutritional compositions, fungi and aflatoxins detection in stored 'gbodo' (fermented Dioscores rotundata) and 'elubo ogede' (fermented Musa parasidiaca) from South western Nigeria. African Journal of Food Science $5,105-110$

[20]. Kaneez FA, Quadiruddin M, Kalhoro MA, Shirrin S, Badar Y (2001) Determination

[21]. of major and trace elements in Artemisia elegantissima and Rhazya stricta and their relative medicinal uses. Pakistan Journal of Science and Industrial Research 44, 291-293

[22]. Komolafe OD, Ishaya EA, Adetola B (2006) Proximate analysis of dika nut Irvinia gabonensis and pepper fruit Dnetia tripetala. International Journal of Food and Agricultural Research 3, 123-127

[23]. Majid AAB, Sarmani S, Yusoff NI, Wei YK, Hamzah F (1995) Trace elements in Malaysian medicinal plants. Journal of Radionanalytical Nuclear Chemistry Articles 195, 173-183

[24]. Mensah JK, Okoli RI, Ohaju-Obodo JO, Eifediyi K (2008) Phytochemical, nutritional and medical properties of some leafy vegetables consumed by Edo people of Nigeria. African Journal of Biotechnology 7, 2304-2309

[25]. Nzikou JM, Mvoula-Tseri M, Matouba E, Quamba JM, Kapseu C, Parmentier

[26]. M, Desobry S (2006) A study on gumbo seed grown in Congo Brazzaville for its food and industrial applications. African Journal of Biotechnology 5, 2469-2475

[27]. Oderinde RA, Ajayi IA, Adewuyi A (2008) Nutritional elements, antibacterial activity and cytotoxity of the leaf, root and stem bark of Blighia unijugata Baker (Sapindaceae) Medicinal and Aromatic Plant Science Biotechnology 2, 137-140

[28]. Odetola AA, Akojeun SM (2000) Anti-diarrhea and gastro-intestinal potentials of the aqeous extract of Phyllantus of the aqeous extract of Phyllantus amarus (Eupthorbiacease). Journal of

[29]. Medical Science 29, 119-122

[30]. Oladele AK, Aina JO (2007) Chemical composition and functional properties of flour produced from two varieties of tigernut (Cyperus esculentus). African Journal of Biotechnology 6, 2473-2476

[31]. Olaniyi AA, Ayin JSK, Ogundaini AO, Olugbade TA (1993) Essential Inorganic and Organic Pharmaceutical Chemistry, Shaneson C.I Ltd., Ibadan, Nigeria, pp 27-90

[32]. Oliver-Berver P (1986) Medicinal Plants in Tropical West Africa, Cambridge University Press, Cambridge, pp 27-146

[33]. Onyeike EN, Acheru GN (2002) Chemical composition of selected Nigerian oilseeds and physical properties of the oil extracts. Food Chemistry 77, 431- 437

[34]. Otitologbon SA, Agbaji EB, Peters OA, Oniye SJ (1997) Proximate and mineral composition of three Nigerian freshwater fishes. Journal of Science, Food and Agriculture 75, 312-314

[35]. Owoyale JA, Olatunji GA, Oguntoye SO (2005) Antifungal and antibacterial

[36]. activities of an alcoholic extract of Senna alata leaves. Journal of Applied Science and Environmental Management 9, 105-107

[37]. Piscator M (1995) Dietary exposure to Cd and health effects: Impact of environmental changes. Environmental Health Perspectives $63,127-132$

[38]. Rossel JB, Pritchard JIR (1991) Analysis of Oilseeds, Fats and Fatty Foods, Elsevier Science Publishers Ltd., The Netherlands, pp 305-308

[39]. Schumacher M, Bosque MA, Domingo JL, Corbella J (1991) Dietary intake of lead and cadmium from foods in Tarrangona Province, Spain. Bulletin of Environmental Contaminant and Toxicology 46, 320-328

[40]. Schwart MK (1975) Role of trace elements in cancer. Cancer Research 35, 3481-3484

[41]. Sherlock J, Smart GA, Walters B (1983) Dietary surveys on a population at Shipham, Somerset, United Kingdom. Science of the Total Environment 29, 121-142 
[42]. Sofowora A (1993) Medicinal Plants and Traditional Medicine in Africa ( $2^{\text {nd }}$ Edn), Spectrum Books Ltd., Sunshine House, Ibadan pp $1-257$

[43]. Trease GE, Evans WC (1989) A Textbook of Pharmacognosy, pp 166, 469-471

[44]. Uddoh CK (1998) Nutrition, Macmillan Publishers Ltd., London, UK, pp 71- 97

[45]. Vartika R, Poonam K, Rawat AKS, Shantan M (2001) Heavy metal accumulation in some herbal drugs. Pharmaceutical Biology 39, 384-387

\begin{tabular}{|c|c|c|c|c|}
\hline Scientific name & Local name & Family name & Medicinal properties & \\
\hline Boerhnaria diffusa & Etipase eranla & Nytaginacae & $\begin{array}{l}\text { Mild laxative, vermifuge, } \\
\text { miscarriage }\end{array}$ & $\begin{array}{l}\text { Oliver-Bever } \\
(1986)\end{array}$ \\
\hline Dissoltis rotundifolia & Apo iba & Malastomaceae & Cough, asthma, pneumonia & Dalziel (1937) \\
\hline Gossypium hirsutum & Eponkon & Malvaceae & $\begin{array}{l}\text { Analgesic, } \\
\text { tuberculosis }\end{array}$ & Dalziel (1937) \\
\hline Mormodica charantia & Ejinrin & Curcubitaceae & Diarrhea, dysentery, & $\begin{array}{l}\text { Oliver-Bever } \\
(1986)\end{array}$ \\
\hline Occimium gratissimum & Efirin & Labiatae & $\begin{array}{l}\text { Antimicrobial, } \\
\text { repellant }\end{array}$ & $\begin{array}{l}\text { Oliver-Bever } \\
(1986)\end{array}$ \\
\hline Paullina pinnata & Kakesenla & Sapindaceae & $\begin{array}{l}\text { Jaundice, yellow fever, } \\
\text { miscarriage }\end{array}$ & $\begin{array}{l}\text { Oliver-Bever } \\
(1986)\end{array}$ \\
\hline Phyllantus reticulata & Iranje & Euphorbiaceae & Malaria, bleeding & Dalziel (1937) \\
\hline Sida acuta & Agidimagbayin & Malvaceae & Catarrh, dysentery, nephritis & Dalziel (1937) \\
\hline Senna alata & Asunrun & Caesalpiniaceae & $\begin{array}{l}\text { Chronic gonorrhea antifungal } \\
\text { ringworm }\end{array}$ & $\begin{array}{l}\text { Owoyale et al., } \\
(2005)\end{array}$ \\
\hline Senna podocarpa & Ajanrere & Caesalpiniaceae & Dysentery & $\begin{array}{l}\text { Oliver-Bever } \\
(1986)\end{array}$ \\
\hline
\end{tabular}

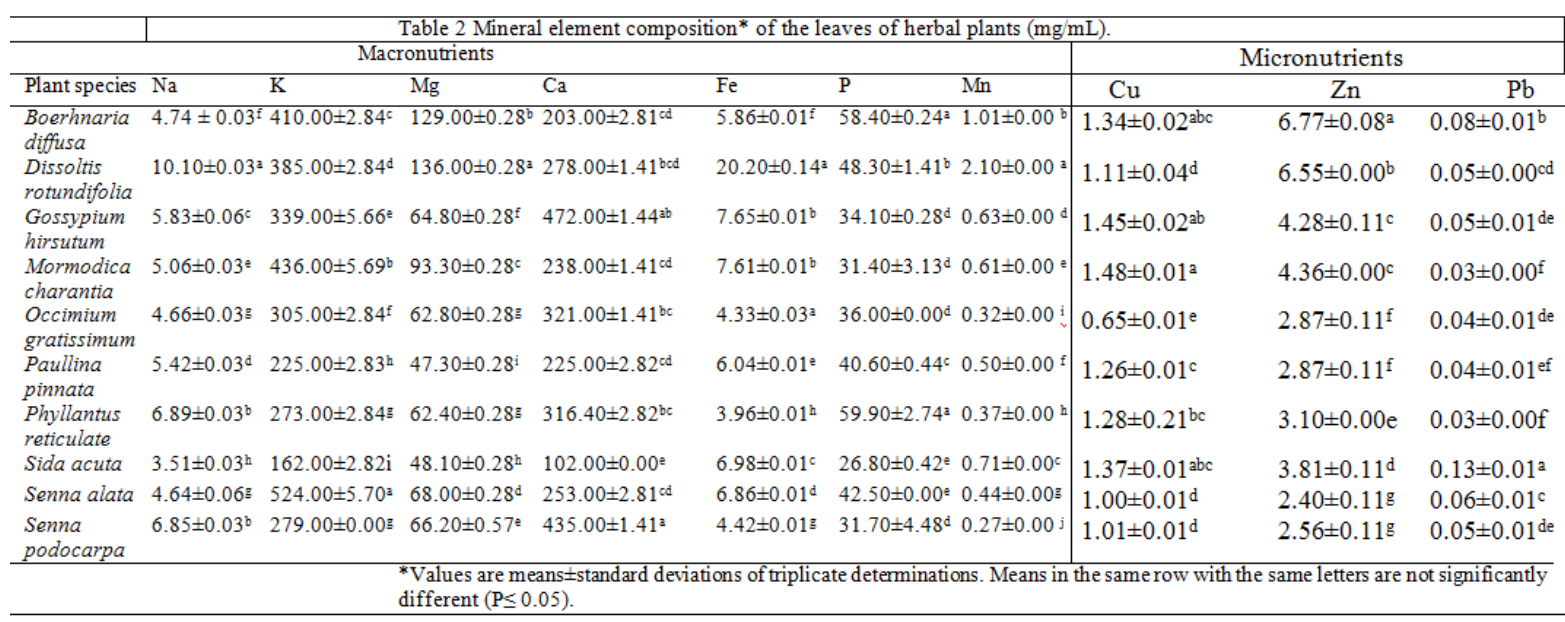


Table 3 Mineral element composition $(\mathrm{mg} / 100 \mathrm{~g})$ of some plant species by some authors

\begin{tabular}{|c|c|c|c|c|c|c|c|c|c|c|}
\hline $\begin{array}{l}\text { Plant } \\
\text { Species }\end{array}$ & $\mathrm{Na}$ & $\mathrm{K}$ & $\mathrm{Mg}$ & $\mathrm{Ca}$ & $\mathrm{Fe}$ & $\mathrm{P}$ & $\mathrm{Mn}$ & $\mathrm{Cu}$ & $\mathrm{Zn}$ & $\mathrm{Pb}$ \\
\hline $\mathrm{AD}^{\mathrm{a}}$ & 136.900 & 32.000 & 145.070 & 120.600 & 0.527 & NA & NA & 0.000 & 0.014 & 0.002 \\
\hline $\mathrm{AM}^{\mathrm{a}}$ & 12.600 & 100.700 & 96.000 & 21.500 & 11.3000 & NA & NA & 0.167 & 1.555 & 0.002 \\
\hline $\mathrm{PC}^{\mathrm{a}}$ & 101.800 & 151.700 & 406.000 & 32.300 & 6.800 & NA & NA & 0.006 & 2.637 & 0.008 \\
\hline $\mathrm{SA}^{\mathrm{a}}$ & 375.000 & 132.500 & 47.500 & 5.100 & 2.730 & NA & NA & 2.740 & 1.530 & 0.175 \\
\hline $\mathrm{VB}^{\mathrm{a}}$ & 70.000 & 230.000 & 65.000 & 315.2 & 0.760 & NA & NA & 6.475 & 0.620 & 0.071 \\
\hline $\begin{array}{l}\text { WMSF }^{\mathrm{b}} \\
\text { PSKF }^{\mathrm{b}}\end{array}$ & $\begin{array}{l}33 \\
38\end{array}$ & $\begin{array}{l}150 \\
1176\end{array}$ & $\begin{array}{l}542 \\
483\end{array}$ & $\begin{array}{l}150 \\
130\end{array}$ & $\begin{array}{l}12.1 \\
10.9\end{array}$ & $\begin{array}{l}127 \\
1090\end{array}$ & $\begin{array}{l}9.9 \\
8.9\end{array}$ & $\begin{array}{l}2.1 \\
1.7\end{array}$ & $\begin{array}{l}10.6 \\
8.2\end{array}$ & $\begin{array}{l}\text { NA } \\
\text { NA }\end{array}$ \\
\hline $\mathrm{PSF}^{\mathrm{b}}$ & 37 & 1279 & 396 & 163 & 14.6 & 989 & 7.2 & 3.72 & 6.7 & NA \\
\hline $\mathrm{CAS}^{\mathrm{c}}$ & $\begin{array}{l}2.30 \pm 0.06 \\
6\end{array}$ & $\begin{array}{l}15.5 \pm 0.06 \\
6\end{array}$ & NA & NA & $\begin{array}{l}0.293 \pm 0.00 \\
1\end{array}$ & NA & NA & $\begin{array}{l}0.151 \pm 0.00 \\
1\end{array}$ & NA & $0.004 \pm 0.01$ \\
\hline $\operatorname{COS}^{\mathrm{c}}$ & $\begin{array}{l}2.53 \pm 0.00 \\
1\end{array}$ & $\begin{array}{l}15.4 \pm 0.00 \\
1\end{array}$ & NA & NA & $\begin{array}{l}0.489 \pm 0.00 \\
1\end{array}$ & NA & NA & $\begin{array}{l}0.200 \pm 0.00 \\
1\end{array}$ & NA & $0.002 \pm 0.01$ \\
\hline $\mathrm{DS}^{\mathrm{c}}$ & $\begin{array}{l}2.02 \pm 0.06 \\
6\end{array}$ & $\begin{array}{l}15.6 \pm 0.01 \\
1\end{array}$ & NA & $\mathrm{NA}$ & $\begin{array}{l}0.315 \pm \\
0.00\end{array}$ & NA & NA & $\begin{array}{l}0.139 \pm \\
0.00\end{array}$ & NA & $\begin{array}{l}0.054 \pm 0.00 \\
1\end{array}$ \\
\hline $\mathrm{GS}^{\mathrm{c}}$ & $\begin{array}{l}1.90 \pm 0.06 \\
6\end{array}$ & $\begin{array}{l}16.2 \pm \\
0.01\end{array}$ & NA & NA & $\begin{array}{l}0.130 \pm 0.00 \\
1\end{array}$ & NA & NA & $\begin{array}{l}0.126 \pm 0.00 \\
1\end{array}$ & NA & $\begin{array}{l}0.066 \pm \\
0.001\end{array}$ \\
\hline $\mathrm{MS}^{\mathrm{c}}$ & $1.2 \pm 0.02$ & $\begin{array}{l}16.5 \pm \\
0.00\end{array}$ & NA & NA & $\begin{array}{l}0.352 \pm 0.00 \\
1\end{array}$ & NA & NA & $\begin{array}{l}0.158 \pm 0.00 \\
1\end{array}$ & NA & $0.076 \pm 0.00$ \\
\hline $\mathrm{OBS}^{\mathrm{c}}$ & $\begin{array}{l}2.65 \pm 0.00 \\
1\end{array}$ & $\begin{array}{l}16.8 \pm \\
0.00\end{array}$ & NA & NA & $\begin{array}{l}0.328 \pm 0.00 \\
1\end{array}$ & NA & NA & $\begin{array}{l}0.233 \pm \\
0.00\end{array}$ & NA & $\begin{array}{l}0.055 \pm \\
0.001\end{array}$ \\
\hline $\mathrm{PKS}^{\mathrm{c}}$ & $\begin{array}{l}1.47 \pm 0.00 \\
1\end{array}$ & $\begin{array}{l}13.4 \pm 0.00 \\
1\end{array}$ & NA & $\mathrm{NA}$ & $\begin{array}{l}0.132 \pm \\
0.00\end{array}$ & NA & NA & $\begin{array}{l}0.162 \pm 0.00 \\
1\end{array}$ & NA & $\begin{array}{l}0.044 \pm \\
0.001\end{array}$ \\
\hline $\mathrm{AO}^{\mathrm{de}}$ & $613 \pm 0.60$ & $6380 \pm 25$ & $1540 \pm 26$ & $6103 \pm 15$ & $35.6 \pm 0.02$ & $100 \pm 2$ & $\begin{array}{l}89.9 \pm \\
0.03\end{array}$ & $2.96 \pm 0.01$ & $\begin{array}{l}3.31 \pm \\
0.02\end{array}$ & $0.44 \pm 0.02$ \\
\hline $\mathrm{AI}^{\mathrm{de}}$ & $138 \pm 0.60$ & $\begin{array}{l}19220 \pm \\
55\end{array}$ & $5630 \pm 12$ & $3543 \pm 15$ & $188 \pm 0.10$ & $\begin{array}{l}900 \pm \\
10\end{array}$ & $\begin{array}{l}46.5 \pm \\
0.04\end{array}$ & $1.12 \pm 0.01$ & $\begin{array}{l}15.7 \pm \\
0.01\end{array}$ & $0.49 \pm 0.03$ \\
\hline $\mathrm{BP}^{\mathrm{de}}$ & $544 \pm 0.03$ & $8170 \pm 16$ & $5380 \pm 10$ & $\begin{array}{l}21850 \pm \\
40\end{array}$ & $96.1 \pm 0.05$ & $\begin{array}{l}300 \pm \\
15\end{array}$ & $\begin{array}{l}31.7 \pm \\
0.06\end{array}$ & $10.3 \pm 0.01$ & $\begin{array}{l}8.87 \pm \\
0.01\end{array}$ & $0.21 \pm 0.02$ \\
\hline $\mathrm{MI}^{\mathrm{de}}$ & $\begin{array}{l}43.6 \pm \\
0.03\end{array}$ & $7470 \pm 15$ & $1372 \pm 9$ & $\begin{array}{l}18810 \pm \\
11\end{array}$ & $46.6 \pm 0.01$ & $100 \pm 4$ & $133 \pm 0.06$ & $3.07 \pm 0.01$ & $\begin{array}{l}3.24 \pm \\
0.01\end{array}$ & $0.29 \pm 0.03$ \\
\hline $\mathrm{ML}^{\mathrm{de}}$ & $176 \pm 0.97$ & $\begin{array}{l}13100 \pm 10 \\
1\end{array}$ & $5470 \pm 59$ & $\begin{array}{l}51340 \pm \\
21\end{array}$ & $122 \pm 0.02$ & $598 \pm 8$ & $685 \pm 0.02$ & $16.5 \pm 0.01$ & $\begin{array}{l}33.6 \pm \\
0.01\end{array}$ & $0.35 \pm 0.01$ \\
\hline $\mathrm{OC}^{\mathrm{de}}$ & $111 \pm 1.18$ & $\begin{array}{l}36600 \pm 35 \\
0\end{array}$ & $3230 \pm 14$ & $\begin{array}{l}32420 \pm \\
52\end{array}$ & $241 \pm 0.05$ & $\begin{array}{l}3700 \pm 3 \\
5\end{array}$ & $\begin{array}{l}51.3 \pm \\
0.04\end{array}$ & $15.1 \pm 0.01$ & $\begin{array}{l}30.8 \pm \\
0.01\end{array}$ & $0.33 \pm 0.02$ \\
\hline $\mathrm{SE}^{\mathrm{de}}$ & $\begin{array}{l}79.6 \pm \\
0.31\end{array}$ & $\begin{array}{l}28750 \pm \\
51\end{array}$ & $3160 \pm 9$ & $7280 \pm 30$ & $178 \pm 0.05$ & $\begin{array}{l}3400 \pm 1 \\
5\end{array}$ & $\begin{array}{l}34.1 \pm \\
0.02\end{array}$ & $21.7 \pm 0.01$ & $\begin{array}{l}24.2 \pm \\
0.01\end{array}$ & $0.31 \pm 0.02$ \\
\hline $\mathrm{ST}^{\mathrm{de}}$ & $\begin{array}{l}78.7 \pm \\
0.49\end{array}$ & $\begin{array}{l}31550 \pm \\
02\end{array}$ & $2460 \pm 70$ & $\begin{array}{l}11390 \pm \\
20\end{array}$ & $208 \pm 0.03$ & $\begin{array}{l}3101 \pm \\
5\end{array}$ & $\begin{array}{l}48.7 \pm \\
0.06\end{array}$ & $13.9 \pm 0.02$ & $\begin{array}{l}23.4 \pm \\
0.01\end{array}$ & $0.34 \pm 0.02$ \\
\hline $\mathrm{ZO}^{\text {de }}$ & $322 \pm 2.00$ & $\begin{array}{l}25280 \pm 11 \\
3\end{array}$ & $4210 \pm 10$ & $2610 \pm 10$ & $144 \pm 0.05$ & $\begin{array}{l}1803 \pm 1 \\
5\end{array}$ & $413 \pm 0.70$ & $14.4 \pm 0.01$ & $\begin{array}{l}33.3 \pm \\
0.01\end{array}$ & $0.26 \pm 0.04$ \\
\hline $\mathrm{HS}^{\mathrm{de}}$ & $\begin{array}{l}72.5 \pm \\
0.05 \\
\end{array}$ & $\begin{array}{l}18260 \pm 23 \\
3\end{array}$ & $4780 \pm 10$ & $19780 \pm 8$ & $142 \pm 0.10$ & $\begin{array}{l}1200 \pm 2 \\
7\end{array}$ & $\begin{array}{l}39.4 \pm \\
0.30 \\
\end{array}$ & $24.4 \pm 0.01$ & $\begin{array}{l}35.1 \pm \\
0.01 \\
\end{array}$ & $0.28 \pm 0.02$ \\
\hline
\end{tabular}

